\title{
Environmental Scanning Electron Microscopy of the Infection Process of Fusarium solani f. sp. passiflorae in Seedlings of Passionfruit (Passiflora edulis f. flavicarpa)
}

\author{
Jacobo Robledo-Buriticá, Carolina Ángel-García, Jairo Castaño-Zapata*
}

Departamento de Producción Agropecuaria, Facultad de Ciencias Agropecuarias, Grupo de Investigación y Proyección Producción Agropecuaria (GIPPA), Universidad de Caldas, Manizales, Colombia

\begin{abstract}
Environmental scanning electron microscopy (ESEM) was performed in seedlings of Passiflora edulis f. flavicarpa inoculated with Fusarium solani f. sp. passiflorae (teleomorph: Haematonectria haematococca) causal agent of passionfruit collar rot. Inoculations were carried out every $24 \mathrm{~h}$ until the seventh day and from this day until the fifteenth the interval of inoculation was $72 \mathrm{~h}$. The pathogen isolated in PDA media was placed on the surface of the collar through the modified test-tube screening methodology. Epidermis of collar, stem, and leaves and longitudinal sections of collar and stem were observed. After $24 \mathrm{~h}$ of inoculation, conidia and dense septate mycelium were observed over the epidermis of the stem and the collar, respectively. Hypertrophy and cell wall degradation of the vascular tissues were also found during this period. Five days after the inoculation macroconidia were formed from monophialides in the aerial mycelium on the stem. Ten days after inoculation, xylem and pith cells of the collar were colonized by hyphae, inclusions, and mature sporodoquia over the stem surface. Hyphae colonization started six days after inoculation on stomata and thirteen days after inoculation monophialides with in situ microconidia were observed over the surface of the leaves. Based on the evidence and previous studies, internal hyphae colonization of $F$. solani f. sp. passiflorae concentrates on the collar area and the damages of the cells indicate an extracellular enzymatic activity of the fungus. The incubation and latent periods of $F$. solani f. sp. passiflorae were 1.4 and 4 days, respectively. (C) 2017. Acad. Colomb. Cienc. Ex. Fis. Nat.
\end{abstract}

Key Words: Plant diseases; fungal diseases; Passifloraceae; collar rot; scanning microscopy.

Microscopía electrónica de barrido ambiental del proceso de infección de Fusarium solani f. sp. passiflorae en plántulas de maracuyá (Passiflora edulis f. flavicarpa)

\section{Resumen}

Se realizó microscopía electrónica de barrido ambiental (ESEM) en plántulas de maracuyá (Passiflora edulis f. flavicarpa) inoculadas con Fusarium solani f. sp. passiflorae (teleomorfo: Haematonectria haematococca) agente causal de la secadera. Las inoculaciones se realizaron cada 24 h hasta el séptimo día y hasta el día quince el intervalo fue de $72 \mathrm{~h}$. El aislamiento en medio de papa (PDA) se colocó sobre el cuello de la raíz mediante la metodología de cribado en tubos de ensayo modificada. La superficie del cuello, tallo, hojas y secciones longitudinales del cuello y tallo fueron observadas. Después de 24 h de la inoculación, se observaron conidios y micelio denso septado sobre la epidermis del tallo y el cuello e hipertrofia y degradación de la pared celular de los tejidos vasculares. Al quinto día se formaron macroconidios a partir de monofiálides en el micelio aéreo en el tallo. Diez días después, las células del xilema y médula del cuello fueron colonizadas por hifas, esporodoquios maduros e inclusiones. La colonización de las estomas por las hifas comenzó seis días después de la inoculación y trece días después de la inoculación se observaron monofiálides con microconidios in situ sobre la superficie foliar. Basados en la evidencia y estudios previos, la colonización interna por hifas de $F$. solani f. sp. passiflorae se concentra en el área del cuello y los daños de las células indican una actividad enzimática extracelular del hongo. El periodo de incubación y latencia de F. solani f. sp. passiflorae fue de 1,4 y 4 días, respectivamente. (C) 2017. Acad. Colomb. Cienc. Ex. Fis. Nat.

Palabras clave: Enfermedades de plantas; Enfermedades fungosas; Passifloraceae; Pudrición del cuello; Microscopía de barrido.

\footnotetext{
*Corresponding autor:

Jairo Castaño-Zapata, jairo.castano_z@ucaldas.edu.co; Received: April 28, 2017; Accepted: June 9, 2017
} 


\section{Introduction}

Yellow passionfruit (Passiflora edulis f. flavicarpa Degener) is one of the most important fruits of Passiflora genus and Passifloraceae family (Isaacs, 2009; Miranda, et al. (2008); Ocampo, 2007; Souza, et al, 2002). Passionfruit is widely used in the food industry due to its edible qualities while passionflower (flowers of $P$. edulis) is recognized by its effects in the Central Nervous System and its implementation in traditional medicine in South America and India (Patel, 2009; Montanher, et al., 2007; Ocampo, 2007). However, many diseases in the plantations of $P$. edulis $\mathrm{f}$. flavicarpa decrease yield, reduce productive life of the plants, and in some cases, can completely destroy the crops (Vaca-Vaca, et al., 2016; Ocampo, et al., 2013; Cavichioli, et al., 2011; Fischer, et al., 2010; Fischer, et al., 2005).

Diseases in passionfruit crops caused by phytopathogenic species of Fusarium genus produce significant crop losses (Oliveira-Freitas, et al., 2016; Preisigke, et al., 2015a; Preisigke, et al., 2015b; Silva, et al., 2013; Fischer, et al., 2010; Bueno, 2009). Although four species of fungi belonging to Fusarium have been described producing symptoms in P. edulis f. flavicarpa in Colombia, Fusarium oxysporum Schltdl. and F. solani f. sp. passiflorae proposed by Bueno, et al. (2014) [teleomorph: Haematonectria haematococca (Berk. \& Broome) Samuels \& Rossman] represent the most common source of Fusarium wilt (Ortíz, et al., 2014; Londoño, 2012; Gardner, 1989). Both F. oxysporum and $F$. solani produce structural damages in xylem, phloem, cambium, and parenchymatous cells (Saniewska, Dyki, \& Jarecka, 2004; Bishop \& Cooper, 1983). However, F. oxysporum penetrates through the roots and moves into the vascular system and $F$. solani $\mathrm{f}$. sp. passiflorae concentrates in the collar area causing the collar rot disease of $P$. edulis (Ortíz, et al., 2014).

Plants of $P$. edulis infected by Haematonectria haematococca (Anamorph: F. solani f. sp. passiflorae) present a progressive loss of vigor, wilt, defoliation, roughness in the fruits, chlorosis, vascular necrosis, eventually perithecia formation, collar rot and finally death (Ortíz \& Hoyos, 2012). F. solani is favored by high temperature and relative humidity. Irrigation water, rainfalls, and wind are dissemination factors of reproductive structures of the fungus (Nelson, Toussoun, \& Marasas, 1983). Chemical and biological control of passionfruit collar rot is ineffective due to the presence of resistance structures of $F$. solani (chlamydospores) in the soil for long periods of time. This fact forces to eradicate complete crops and performs the cultivation in new areas free from the pathogen (Flores, et al., 2012; Londoño, 2012; Castaño-Zapata, 2009; Agrios, 2005; Nelson, Dignani, \& Anaissie, 1994).

Histopathological features of plants of passionfruit infected by $F$. solani f. sp. passiflorae and its symptomatology associated with collar rot have been studied in detail (Ortíz, et al., 2014; Ortíz \& Hoyos, 2012). However, damages produced by this pathogen in the surface of the plant and its progress over time in $P$. edulis f. flavicarpa are not well known. This study aims to perform environmental scanning electron microscopy (ESEM) in P. edulis f. flavicarpa seedlings inoculated with $F$. solani $\mathrm{f}$. sp. passiflorae observing the progress of the damages over time.

\section{Materials and methods}

Seeds of Passiflora edulis f. flavicarpa, obtained from susceptible commercial crops located in the department of Caldas (Colombia), were planted under controlled conditions of temperature and light at $29^{\circ} \mathrm{C}$ and $12 \mathrm{~h}$ photoperiod in autoclaved soil. When seeds germinated and reached two true leaves (three to four weeks after planting), they were carefully removed from the soil and disinfested by immersing each seedling in $2 \%$ sodium hypochlorite and $70 \%$ ethanol for 2 minutes and 50 seconds, respectively. Posteriorly, seedlings were washed with sterile distillated water and inoculated by placing a segment of potato dextrose agar (PDA) media with the fungus using the modified testtube screening methodology proposed by Ángel-García, Robledo-Buriticá, \& Castaño-Zapata (submitted Boletín Científico Centro de Museos, 2017). Inoculations were carried out in three seedlings every $24 \mathrm{~h}$ until the seventh day. From this day to the fifteenth day the interval of inoculation was $72 \mathrm{~h}$. Inoculated seedlings grew up under the same conditions previously mentioned.

The monosporic isolate of $F$. solani f. sp. passiflorae MViRi01 was used as inoculum. This isolate was tested for its pathogenicity following the Koch's postulates. Morphological characterization was performed through optical and electronic microscopy on carnation leaf agar (CLA) and PDA media (Figure 1) following the recommendations of Leslie \& Summerell (2006). For the inoculation, F. solani f. sp. passiflorae MViRi01 was cultivated in PDA media until reproductive structures (microconidia) were observed.

Samples of $5 \mathrm{~mm}$ length of the external surface (Figure 2A) and longitudinal section (Figure 2B) of tissues from collar, stem and leaves of each inoculated plant were observed. Sections of the tissues were operated manually after treating them at temperature of $4^{\circ} \mathrm{C}$ for two minutes. Every tissue was summited to an amplification of 200x, 500x, 1000x, 2000x, 5000x, and a maximum of 8000x. The total number of observations was 30 plants.

Observation was carried out by using a scanning electron microscope FEI-QUANTA FEG 250 in environmental scanning electron microscopy (ESEM ${ }^{\mathrm{TM}}$ ) mode at low vacuum (2.600 Pa) and at an acceleration voltage of $10 \mathrm{kV}$. Images were analyzed by using the software Image J (Schneider, Rasband, \& Eliceiri, 2012).

\section{Results}

Surface and longitudinal section of the collar. Epidermal cells of the collar of non-inoculated seedlings of $P$. edulis $\mathrm{f}$. flavicarpa presented a rectangular, semi-square, and polygonal shape with an average surface area of $536.2 \mu \mathrm{m}^{2}$, well-defined 

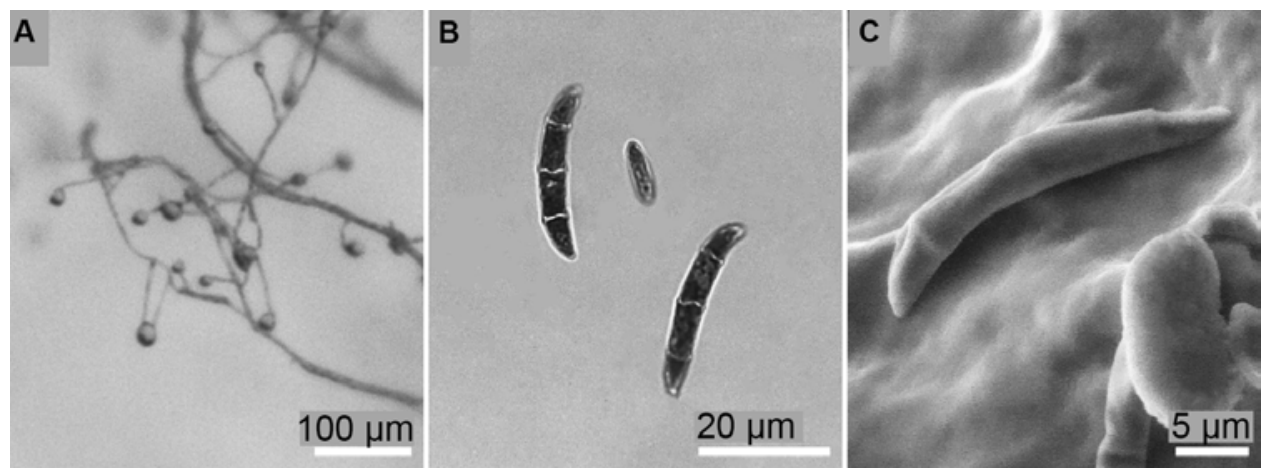

Figure 1. Morphological features of F. solani MViRi01 isolate on CLA. (A) Monophialides with microconidia in situ . (B) Macroconidia and microconidium. (C) Scanning electron microscopy of a macroconidium.
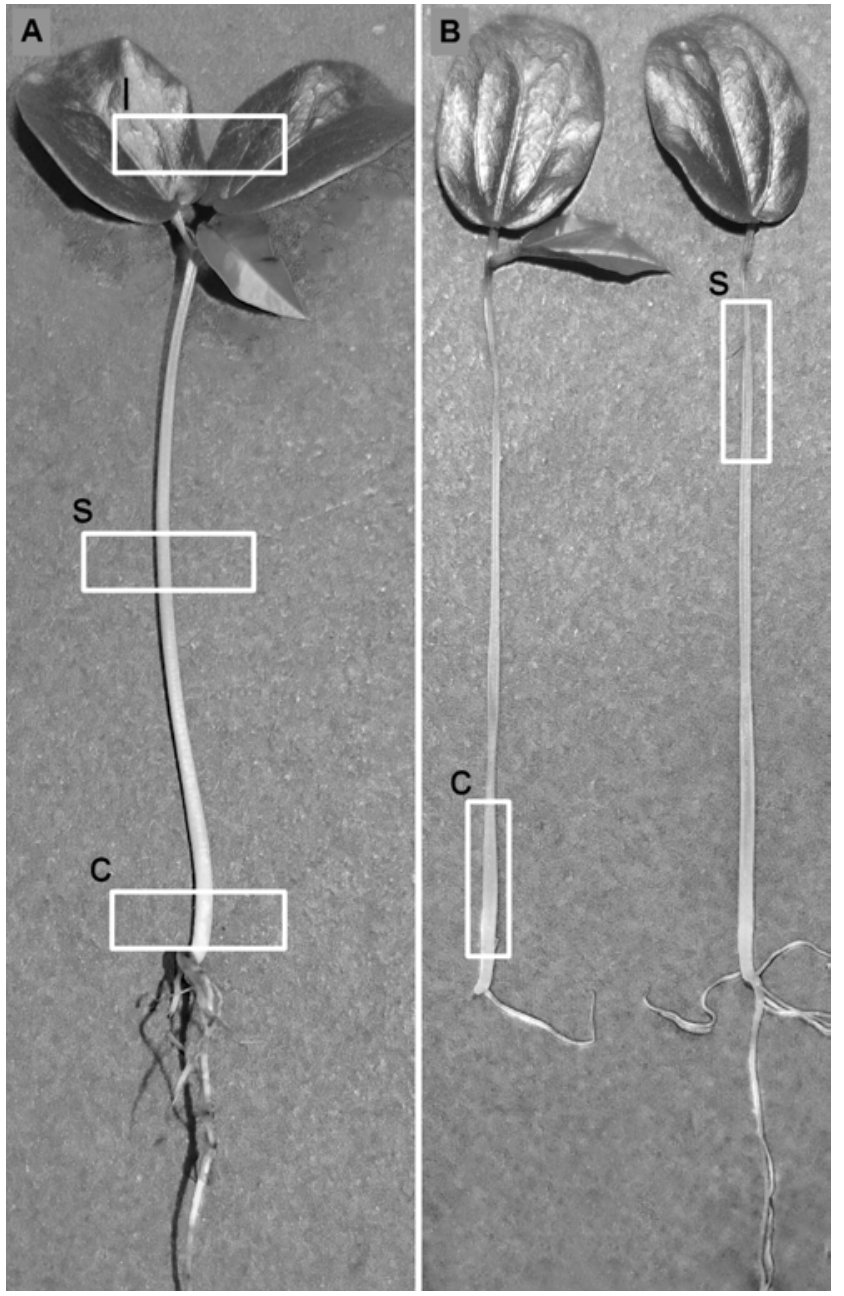

Figure 2. Observed areas in P. edulis f. flavicarpa seedlings. (A) Examination sites on the surface of the seedling: $c$, collar; $s$, stem; $l$, leaves. (B) Examination sites of longitudinal sections of the seedling: $c$, collar; $s$, stem.

cell walls, and complete absence of hyphae and reproductive structures of the fungus (Figure 3A, B). Inoculated plants $24 \mathrm{~h}$ after inoculation were deeply overgrown with septate hyphae

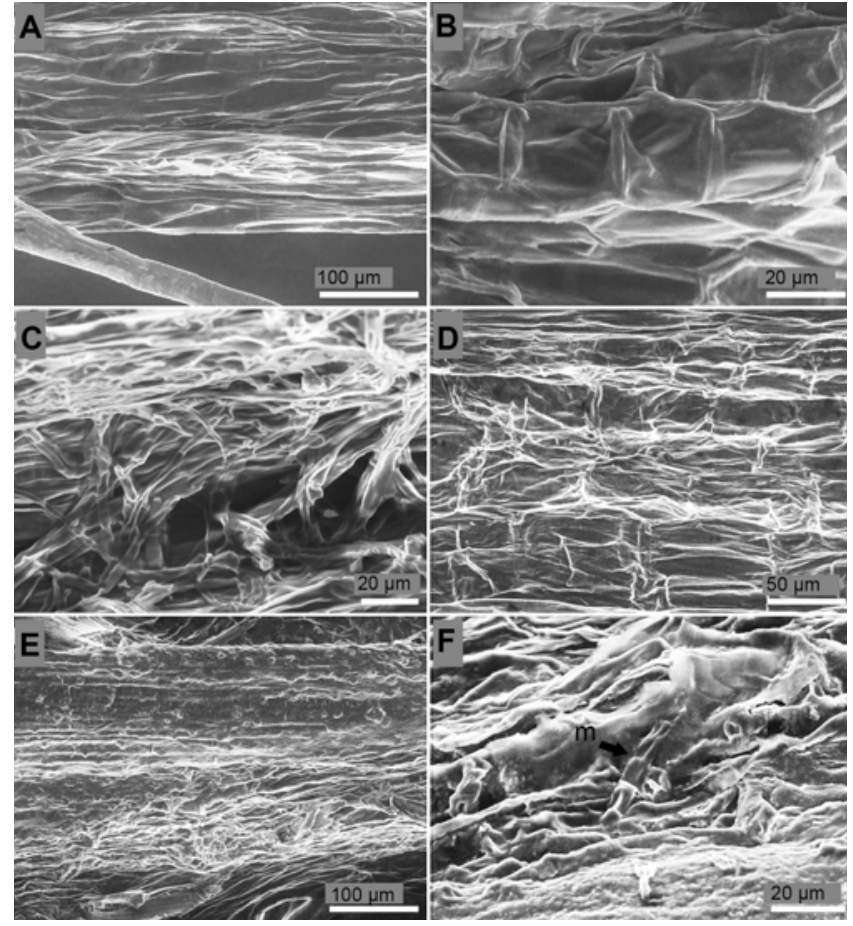

Figure 3. Surface of the collar of $P$. edulis $\mathrm{f}$. flavicarpa seedlings. (A, B) Surface of the collar of non-inoculated seedling. (C) Septate hyphae colonization over the surface of the collar $24 \mathrm{~h}$ after inoculation. (D) Cell wall degradation and loss of turgor pressure of the epidermal cells of the collar four days after inoculation. (E) Degradation of the epidermis of the collar ten days after inoculation. (F) Single macrocodium $(m)$ on rot tissues over the epidermis of the collar ten days after inoculation.

causing moderate rugosity over the collar epidermis (Figure 3C). Epidermal cells of the collar four days after inoculation showed severe rugosity, 25\% reduction of the cell wall thickness, and cell wall collapse (Figure 3D). Collar cells of the seedlings ten days after inoculation were unrecognizable, cell walls were not distinguished, the collar total width was reduced from $539.7 \mu \mathrm{m}$ to $258.3 \mu \mathrm{m}$, and the tissue presented a heterogeneous texture indicating 
rot (Figure 3E). Although reproductive structures were not observed massively in the collar surface, some areas of the collar presented disperse macroconidium (Figure 3F).

Longitudinal section of the collar of non-inoculated seedlings presented parenchymatous elongated cells in the center (pith or medulla) separated by an average length of $126.9 \mu \mathrm{m}$. Xylem cells surrounded pith cells and subsequently phloem cells encircled xylem cells. No hyphae or conidia were found in the collar of non-inoculated seedlings (Figure 4A, B). Pith cells ten days after inoculation suggested the presence of inclusions (Figure 4C) and hyphae colonization (Figure 4C, D). Phloem and xylem cells developed hypertrophy, degradation of the cell wall, and rot (Figure 4E). No conidia were found inside the tissue of the collar.

Surface and longitudinal section of the stem. Stem surface of non-inoculated seedlings of $P$. edulis $\mathrm{f}$. flavicarpa were completely free from mycelia and conidia (Figure 5A). On the surface of the seedlings 24 hours after inoculation straight and slightly curved macroconidia of $36 \mu \mathrm{m}$ length, blunt apical cell, and barely notched basal cell were observed. Microconidia of $8.3 \mu \mathrm{m}$ length, ellipsoid, reniform and fusiform shape were also detected (Figure 5B). Five days after inoculation formation of macroconidia in a dense non mature sporodochium and aerial mycelium in short monophialides were distinguished (Figure 5C, D). During this period abundant mycelium was observed around the stem (Figure 5E). Ten days after inoculation microconidia were developed in relatively long and abundant monophialides (Figure 5F). Thirteen days after inoculation sporodochia were fully developed (Figure 5G) and monophialides with microconidia in situ reached a spherical shape with equal longitudinal and transversal radio of $9.9 \mu \mathrm{m}$ length (Figure $5 \mathrm{H}$ ).

Rectangular elongated cells with cell walls well defined composed the healthy stem from non-inoculated seedlings (Figure 6A). Phloem cells from 24 hours after inoculation seedlings presented degradation. However, xylem cells did not acquire any damage (Figure 6B) and tracheid side-to-side hyphae colonization was not seen (Figure 6C). Four days after inoculation both phloem and cortex cells presented rugosity indicating water deficit (Figure 6D). Five days after inoculation structure of the cells of stem of inoculated seedlings was destroyed, no cell walls were distinguished, and cell structure was non-functional (Figure 6E). Similar results were obtained seven days after inoculation (Figure 6F).

Surface of the leaves. Fusarium structures over the leaf surface came out from stomata six days after inoculation (Figure 7B). Leaf surface of non-inoculated seedlings were not overgrowth with mycelia of the fungus and stomata were free from any sign of the pathogen (Figure 7A, D). Thirteen days after inoculation monophialides appeared. Apical cell (false heads) of monophialides was joined to a relatively long conidiophore (74 $\mu \mathrm{m}$ length). Microconidia in situ were observed thirteen days after inoculation in leaf surface (Figure 7C) while macroconidia were not observed in these tissues. Deep colonization of leaf surface was carried out thirteen days after inoculation (Figure 7E).

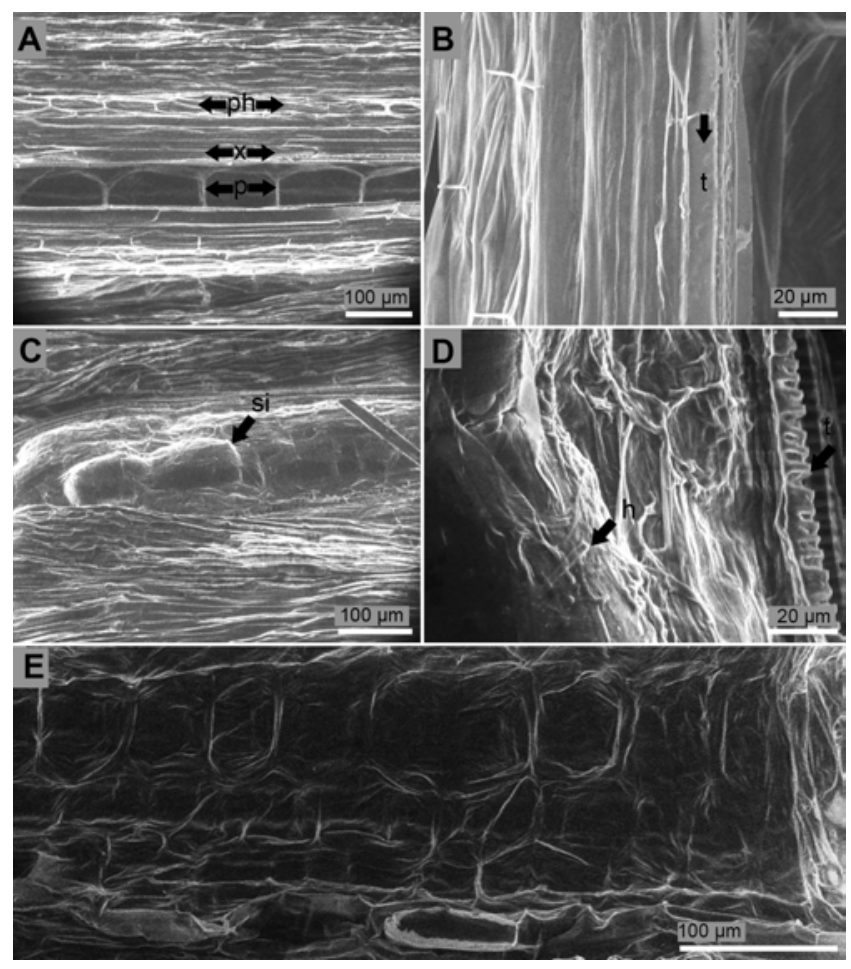

Figure 4. Longitudinal section of the collar of $P$. edulis f. flavicarpa seedlings. (A, B) Non-inoculated seedling: $p$, pith; $p h$, phloem; $x$, xylem; $t$, tracheid. (C) Suggested inclusion (si) inside pith cells of the collar ten days after inoculation. (D) Hyphae $(h)$ colonization of the inner tissues of the collar ten days after inoculation: $t$, tracheid. (E) Degraded cells and cell walls of the inner tissues of the collar ten days after inoculation.

\section{Discussion}

Environmental scanning electron microscopy (ESEM) performed in this study allowed to reveal the presence, progress, distribution and localization of $F$. solani f. sp. passiflorae hyphae and reproductive structures (macro and microconidia) on the surface of collar, stem, and the leaves of infected $P$. edulis f. flavicarpa seedlings. The results suggest that, even though mycelium was detected in the external of both leaves and stem, faster and larger amount of hyphae colonization appear over the collar surface and concentrate on the collar internal tissues after hyphae penetrate from the epidermis to the xylem and pith. These observations coincide with studies developed on seedlings of pea inoculated with Fusarium solani f. sp. pisi that claim that infection of this pathogen can start at the base of the stem or stomata through directly cuticle degradation via cutinase enzymes (Pietro, et al., 2003; Rogers, Flaishman, \& Kolattukudy, 1994; Köller, Allan, \& Kolattukudy, 1982; Shaykh, Soliday, \& Kolattukudy, 1977). Natural infection of Fusarium solani in $P$. edulis f. flavicarpa occurs from the periderm to the pith of the collar tissues directly associated with symptoms observed in the field (Ortíz, et al., 2014; Ortíz \& Hoyos, 2012). 

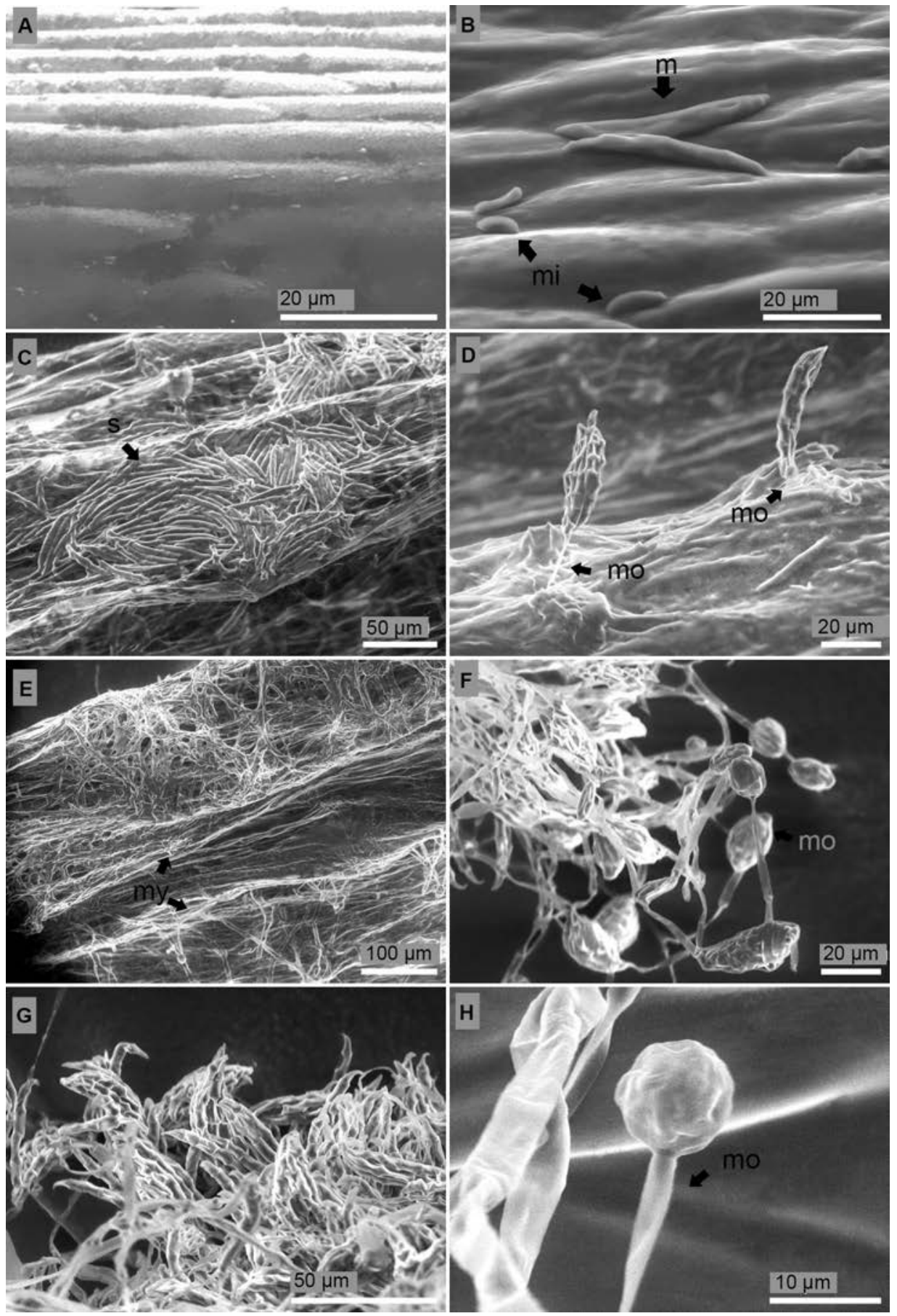

Figure 5. Surface of the stem of P. edulis f. flavicarpa seedlings. (A) Non-inoculated seedling. (B) Macro $(\mathrm{m})$ and microcodia ( $m i) 24$ h after inoculation. (C) Non-mature sporodochium (s) five days after inoculation. (D) Monophialides (mo) containing macroconidia five days after inoculation. (E) Dense mycelium ( $m y$ ) five days after inoculation. (F) Mature sporodochium with monophialides ten days after inoculation. (G) Mature sporodochium thirteen days after inoculation. (H) Monophialide ( $m o$ ) with microconidia in situ thirteen days after inoculation.

The surface of the leaves of inoculated seedlings suggested an infection caused by hyphae. However, hyphae colonization in these tissues was significantly lower compared to those obtained in collar sections. Images from internal tissues of the stem did not reveal presence of hyphae. Nevertheless, hypertrophy, cell wall degradation, losses of turgor pressure in the cells, and rot was observed in stem internal tissues. These symptoms are likely a sign of enzymatic activity produced by the fungus (Ortíz, et al., 2014; Köller, et al., 1982; Bateman \& Basham, 1976). According to Bueno, et al. (2009) different isolates of $F$. solani f. sp. passiflorae from collar rot tissues of $P$. edulis f. flavicarpa 

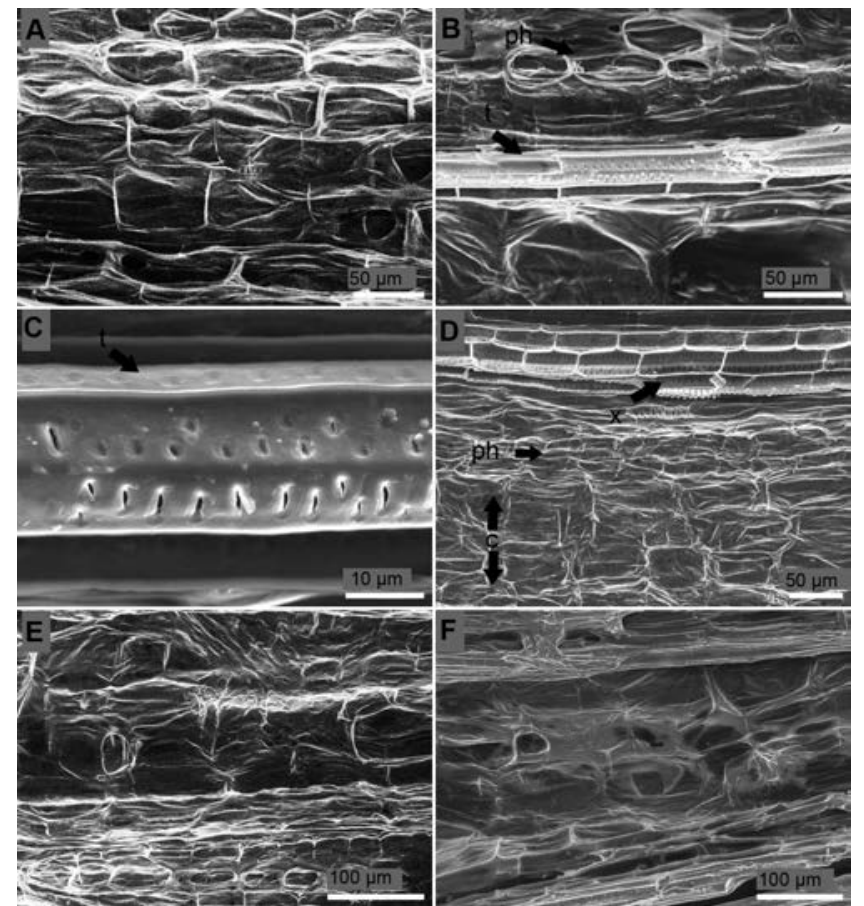

Figure 6. Longitudinal section of the stem of $P$. edulis f. flavicarpa seedlings. (A) Non-inoculated seedling. (B) Degraded vascular vessels 24 hours after inoculation: $t$, tracheid; $p h$, phloem. (C) Tracheid $(t)$ with no signs of side-to-side hyphae colonization $24 \mathrm{~h}$ after inoculation. (D) Losses of turgor pressure of parenchymatous cells of the cortex four days after inoculation: $c$, cortex; $p h$, phloem; $x$, xylem. (E) Rot tissues five days after inoculation. (F) Rot tissues seven days after inoculation.

produce extracellular enzymes such as amylase, lipase, cellulase, protease, and lacase. Some similar symptoms of cell degradation have been reported in wheat infected by $F$. culmorum and F. graminearum (Jackowiak, et al., 2005; Kang \& Buchenauer, 2002; Schwarz, et al., 1997; Meyer, Weipert, \& Mielke, 1986) banana infected by $F$. oxysporum f. sp. cubense (Meiting \& Shaosheng, 2010), potato infected by F. roseum (Mullen \& Bateman, 1975), and maize infected by F. graminearum (Gao, et al., 2004).

According to Ángel-García, Robledo-Buriticá, CastañoZapata (submitted Boletín Cinetífico Centro de Museos, 2017) the first symptoms of collar rot of P. edulis f. flavicarpa seedlings in the modified test-tube screening methodology appear 2.4 days after inoculation. Results obtained in this study show that infection starts within $24 \mathrm{~h}$ after inoculation and 5 days after inoculation reproductive structures of F. solani f. sp. passiflorae were observed. These values suggest an approximate incubation period and latent period (respectively defined by Van der Plank (1963) as the time needed for infection to become visible and the time infected tissues take to become infectious) of 1.4 and 4 days. Similar results have been obtained in $F$. solani f. sp. pisi by Short \& Lacy (1974) who determine that chlamydospores of the pathogen germinate after $24 \mathrm{~h}$ when a germinating seed

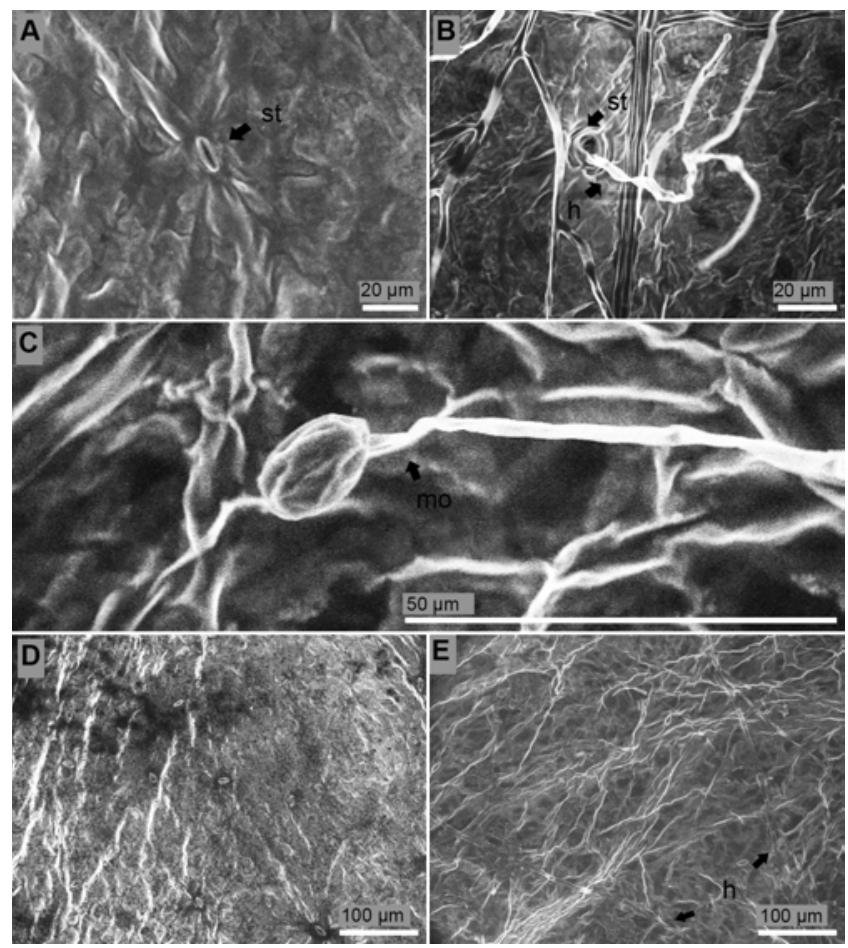

Figure 7. Surface of the leaves of $P$. edulis f. flavicarpa seedlings. (A) Stoma ( $s t)$ of non-inoculated seedling. (B) Hyphae $(h)$ colonized stomata ( $s t$ ) six days after inoculation. (C) Monophialide ( $m o$ ) with micoconiadia in situ thirteen days after inoculation. (D) Healthy leaves. (E) Presence of hyphae $(h)$ thirteen days after inoculation.

is placed $7 \mathrm{~mm}$ away. Shaykh, et al. (1977) also claim that this pathogen began to penetrate the host within 10 $\mathrm{h}$ after inoculation and after $18 \mathrm{~h}$ the hyphae penetrates the tissue.

Although reproductive structures of Fusarium solani $\mathrm{f}$. sp. passiflorae were mainly observed over the surface of the stem and leaves, no conidia were detected into internal tissues, and side-to-side vessel colonization was not confirmed. In addition, images that suggest inclusions inside pith cells of the collar are not conclusive and new studies must be proposed. However, Ortíz, et al. (2014) report that F. solani f. sp. passiflorae possibly colonizes from the collar to the stem through the xylem, microconidia are present among vessel lumen in $P$. edulis tissues, and gels are the most common type of inclusion. Morphology of macroconidia, microconidia and monophialides presented on the stem and leaves surface always coincide with the description of $F$. solani reported by Leslie \& Summerel (2006).

\section{Conclusions}

1. Hyphae of F. solani f. sp. passiflorae colonize collar, stem, and leaves surface of $P$. edulis f. flavicarpa seedlings. However, hyphae colonization of internal structures concentrates on the collar while macroconidia, microconidia, and monophialides concentrate mainly on the stem epidermis and at lower levels on the leaves. 
Rev. Acad. Colomb. Cienc. Ex. Fis. Nat. 41(159):213-220, abril-junio de 2017 doi: http://dx.doi.org/10.18257/raccefyn.471

2. Damages caused in the cell wall of pith, xylem, phloem, and parenchymatous tissues of $P$. edulis f. flavicarpa seedlings, even when hyphae colonization is not present; indicate an extracellular enzymatic activity produced by F. solani f. sp. passiflorae.

3. Based on this study and additional studies, the incubation and latent periods of $F$. solani f. sp. passiflorae inoculated through the modified test-screening methodology in $P$. edulis f. flavicarpa seedlings are 1.4 days and 4 days, respectively

4. Although inclusions in pith cells is suggested in this study and related studies, new research is needed in order to verify this hypothesis.

\section{Acknowledgments}

The authors would like to thank to the GIPPA Research Group of the Universidad de Caldas, doctor Nelson CeballosAguirre, doctor Alejandro Hurtado-Salazar, Engineer Gustavo Adolfo Bolaños-Gallardo, M.Sc. Walter Ricardo López, Mr. Luis Bernardo Gutierrez-Ríos, and Juan Pablo Ríos-Restrepo for their contributions through this study.

\section{Conflict of interest}

The paper was prepared and reviewed with the participation of the authors, who declare that there is no conflict of interest that put in risk the validity of the results obtained in this research.

\section{References}

Agrios, G. N. (2005). Plant pathology (Vol. 5). Burlington: Elsevier Academic Press.

Bateman, D. F., \& Basham, H. G. (1976). Degradation of plant cell walls and membranes by microbial enzymes. In R. Heitefuss, \& P.H. Williams, (eds.). Physiological Plant Pathology. (pp.316-355). Berlin: Springer Berlin Heidelberg.

Bishop, C. D., \& Cooper, R. M. (1983). An ultrastructural study of vascular colonization in three vascular wilt diseases I. Colonization of susceptible cultivars. Physiological Plant Pathology, 23 (3): 323-343.

Bueno, C. J., Fischer, I. H., Rosa, D. D, \& Furtado, E. L. (2009). Production of extracellular enzymes by Fusarium solani from yellow passionfruit. Tropical Plant Pathology, 34 (5): 343-346.

Bueno, C. J., Fischer, I. H., Rosa, D. D., Firmino, A. C., Harakava, R., Oliveira, C. M. G., \& Furtado, E. L. (2014). Fusarium solani f. sp. passiflorae: a new forma specialis causing collar rot in yellow passion fruit. Plant Pathology, 63 (2): 382-389.

Castaño-Zapata, J. (2009). Important diseases of Passifloraceae in Colombia. In D. Miranda, G. Fischer, C. Carranza, S. Magnitskiy, F. Casierra, W. Piedrahíta, \& L.E. Flórez (eds.). Cultivo, Poscosecha y Comercialización de las Pasifloráceas en Colombia: Maracuyá, Granadilla, Gulupa y Curuba. (pp.223-245). Bogotá: Sociedad Colombiana de Ciencias Hortícolas.

Cavichioli, J. C., Corrêa, L. de S., Boliani, A. C., \& Dos Santos, C.P. (2011). Growth and yield of yellow passionfruit grafted on three roostocks. Revista Brasileira de Fruticultura, 33 (2): 558-566.
Infection Process of Fusarium solani f. sp. passiflorae in Passionfruit (Passiflora edulis f. flavicarpa)

Fischer, I. H., de Almeida, A. P., Fileti, M. de S., Bertani, R. M. de A., de Arruda, M. C., \& Bueno, C. J. (2010). Evaluation of passifloraceas, fungicides and Trichoderma for passionfruit collar rot handling, caused by Nectria haematococca. Revista Brasileira de Fruticultura, 32 (3): 709-717.

Fischer, I. H., Lourenço, S. A., Martins, M. C., Kimati, H., \& Amorim, L. (2005). Selection of resistant plants and fungicides for the control of passionfruit collar rot, caused by Nectria haematococca. Fitopatologia Brasileira, 30 (3): 250-258

Flores, P. S., Otoni, W. C., Dhingra, O. D., de Souza Diniz, S. P. S., dos Santos, T. M., \& Bruckner, C. H. (2012). In vitro selection of yellow passionfruit genotypes for resistance to Fusarium vascular wilt. Plant Cell, Tissue and Organ Culture, 108 (1): 37-45.

Gao, H., Chen, J., He, J., Ning, J., Yu, B., Liu, J., \& Ha, J. (2004). The character of cell wall degradation enzyme produced by Fusarium graminearum. Journal of Maize Sciences, 13 (3): 112-113.

Gardner, D. E. (1989). Pathogenicity of Fusarium oxysporum f. sp. passiflorae to banana poka and other Passiflora spp. in Hawaii. Plant Disease, 73 (6): 476-478.

Isaacs, M. (2009). National and international markets of Passifloraceae fruit crops. In D. Miranda, G. Fischer, C. Carranza, S. Magnitskiy, F. Casierra, W. Piedrahíta, \& L.E. Flórez (eds.). Cultivo, Poscosecha y Comercialización de las Pasifloráceas en Colombia: Maracuyá, Granadilla, Gulupa y Curuba. (pp.327-344). Bogotá: Sociedad Colombiana de Ciencias Hortícolas.

Jackowiak, H., Packa, D., Wiwart, M., \& Perkowski, J. (2005). Scanning electron microscopy of Fusarium damaged kernels of spring wheat. International Journal of Food Microbiology, 98 (2): 113-123.

Kang, Z., \& Buchenauer, H. (2002). Studies on the infection process of Fusarium culmorum in wheat spikes: degradation of host cell wall components and localization of trichothecene toxins in infected tissue. European Journal of Plant Pathology, 108 (7): 653-660.

Köller, W., Allan, C. R., \& Kolattukudy, P. E. (1982). Role of cutinase and cell wall degrading enzymes in infection of Pisum sativum by Fusarium solani f. sp. pisi. Physiological Plant Pathology, 20 (1): 47-60.

Leslie, J., \& Summerell, B. (2006). The Fusarium laboratory manual. New York: Blackwell Publishing Professional.

Londoño, J. (2012). Evaluación de la resistencia genética de especies de Passiflora spp. a Fusarium spp. agente causal de la secadera. (M.Sc. Thesis), Universidad Nacional de Colombia, Palmira.

Meiting, L., \& Shaosheng, Z. (2010). Induction of extracellular cell wall-degrading enzymes from Fusarium oxysporum f. sp. cubense and their effect on degradation of banana tissue. Chinese Agricultural Science Bulletin, 5: 048.

Meyer, D., Weipert, D., \& Mielke, H. (1986). Effects of Fusarium culmorum infection on wheat quality. Getreide Mehl. Brot., 40: 35-39.

Miranda, P. M., Carvalho, C. R., Marcelino, F. C., Andréia, M., \& Mendonça, C. (2008). Morphological aspects of Passiflora edulis f. flavicarpa chromosomes using acridine orange banding and rDNA-FISH tools. Caryologia, 61 (2): 154-159. 
Montanher, A. B., Zucolotto, S. M., Schenkel, E. P, \& Fröde, T. S. (2007). Evidence of anti-inflammatory effects of Passiflora edulis in an inflammation model. Journal of Ethnopharmacology, 109 (2): 281-288.

Mullen, J. M., \& Bateman, D. F. (1975). Enzymatic degradation of potato cell walls in potato virus $\mathrm{X}$-free and potato virus $\mathrm{X}$-infected potato tubers by Fusarium roseum 'Avenaceum'. Phytopathology, 65 (7): 797-802.

Nelson, P. E., Dignani, M. C., \& Anaissie, E. J. (1994). Taxonomy, biology, and clinical aspects of Fusarium species. Clinical Microbiology Reviews, 7 (4): 479-504.

Nelson, P. E., Toussoun, T. A., \& Marasas, W. F. O. (1983). Fusarium species: an illustrated manual for identification. Pennsylvania: Pennsylvania State University Press.

Ocampo, J. (2007). Study of the genetic diversity of genus Passiflora L. (Passifloraceae) and its distribution in Colombia. (Ph.D. Thesis). Montpellier: Ecole Nationale Supérieure d'Agronomie de Montpellier - SupAgro.

Ocampo, J., Urrea, R., Wyckhuys, K., \& Salazar, M. (2013). Exploration of the genetic variability of yellow passionfruit (Passiflora edulis f. flavicarpa Degener) as basis for a breeding program in Colombia. Acta Agronómica, 62 (4): 352-360.

Oliveira-Freitas, J. C. de, Viana, A. P., Santos, E. A., Paiva, C. L., de Lima e Silva, F. H., do Amaral Jr., A. T., \& Dias, V. M. (2016). Resistance to Fusarium solani and characterization of hybrids from the cross between $P$. mucronata and P. edulis. Euphytica, 208 (3): 493-507.

Ortíz, E., \& Hoyos, L. (2012). Description of the symptomatology associated with fusariosis and its comparison with other diseases for the purple passionfruit (Passiflora edulis Sims.) in the Sumapaz region (Colombia). Revista Colombiana de Ciencias Hortícolas, 6 (1): 110-116.

Ortíz, E., Cruz, M., Melgarejo, L. M., Marquínez, X., \& Hoyos-Carvajal, L. (2014). Histopathological features of infections caused by Fusarium oxysporum and F. solani in purple passionfruit plants (Passiflora edulis Sims). Summa Phytopathologica, 40 (2): 134-140.

Patel, S. S. (2009). Morphology and pharmacology of Passiflora edulis: a review. Journal of Herbal Medicine and Toxicology, 3 (1): 1-6.

Pietro, A. D., Madrid, M. P., Caracuel, Z., Delgado-Jarana, J., \& Roncero, M. I. G. (2003). Fusarium oxysporum: exploring the molecular arsenal of a vascular wilt fungus. Molecular Plant Pathology, 4 (5): 315-325.
Preisigke, S. da C., Martini, F. V., Rossi, A. A. B., Serafim, M. E., Barelli, M. A. A., da Luz, P. B., \& Neves, L. G. (2015a). Genetic variability of Passiflora spp. against collar rot disease. Australian Journal of Crop Science, 9 (1): 69-74.

Preisigke, S. da C., Neves, L. G., Araújo, K. L., Barbosa, N. R., Serafim, M. E., \& Krause, W. (2015b). Multivariate analysis for the detection of Passiflora species resistant to collar rot. Bioscience Journal, 31 (6): 1700-1707.

Rogers, L. M., Flaishman, M. A., \& Kolattukudy, P. E. (1994). Cutinase gene disruption in Fusarium solani f. sp. pisi decreases its virulence on pea. The Plant Cell, 6 (7): 935-945.

Saniewska, A., Dyki, B., \& Jarecka, A. (2004). Morphological and histological changes in tulip bulbs during infection by Fusarium oxysporum f. sp. tulipae. Phytopathologia Polonica, 34: 21-39.

Schneider, C. A., Rasband, W. S., \& Eliceiri, K. W. (2012). NIH Image to ImageJ: 25 years of image analysis. Nature Methods, 9 (7): 671-675.

Schwarz, P., Casper, H., Barr, J., \& Musial, M. (1997). Impact of Fusarium head blight on the malting and brewing quality of barley. Cereal Research Communications, 813-814.

Shaykh, M., Soliday, C., \& Kolattukudy, P. E. (1977). Proof for the production of cutinase by Fusarium solani f. pisi during penetration into its host, Pisum sativum. Plant Physiology, 60 (1): 170-172.

Short, G.E., \& Lacy, M.L. (1974). Germination of Fusarium solani f. sp. pisi chlamydospores in the spermosphere of pea. Phytopathology, 64: 558-562.

Silva, S., Oliveira, E. J. de, Haddad, F., Laranjeira, F. F., Jesus, N. de, Oliveira, S. A. S. de, ... do Amaral Jr., A. T. (2013). Identification of passionfruit genotypes resistant to Fusarium oxysporum f. sp. passiflorae. Tropical Plant Pathology, 38 (36): 236-242.

Souza, M. M. de, Santana-Pereira, T. N., Hoffmann, M., Melo, E. J. T. de, \& Pereira-Louro, R. (2002). Embryo sac development in yellow passionfruit Passiflora edulis f. flavicarpa (Passifloraceae). Genetics and Molecular Biology, 24 (4): 471-475.

Vaca-Vaca, J. C., Carrasco-Lozano, E. C., Rodríguez-Rodríguez, M., Betancur-Perez, J. F. and López-López, K. (2016). First report of a begomovirus presents in yellow passionfruit [Passiflora edulis f. flavicarpa (Degener)] in Valle del Cauca, Colombia. Revista Colombiana de Biotecnología, 18 (2): 56-65.

Van der Plank, J. E. (1963). Plant diseases: epidemics and control. New York: Elsevier Academic Press. 